record of an undoubted Charophyte. It is considered that this species was probably a land plant, growing like the recent and contemporary Charas in fresh and brackish water.

\section{Central American Flora}

THE very rich floristic region of Central America has long attracted taxonomic botanists. In a recent work ("Flora of Guatemala", by P. C. Standley and J. A. Steyermark. Fieldiana: Botany, 24, Pt. III, published by Chicago Natural History Museum, April 1952), the authors have dealt with the major monocotyledonous families from Commelinaceæ and Pontederiaceæ to Cannaceæ and Burmanniaceæ, and with dicotyledonous families including Casuarinaceæ and Piperaceæ to Fagaceæ and Urticaceæ. Some excellent line-illustrations accompany the text.

\section{Sunspots during January-April 1952}

An account by Lucy T. Day of the positions, areas and counts of sunspots during the period JanuaryApril 1952 is given in United States Naval Observatory Circular No. 36 (June 18, 1952). The results, tabulated in seven pages of the Circular, are based upon measurements made at the Naval Observatory on plates secured there or at the Mt. Wilson Observatory, and are a continuation of those published in the Monthly Weather Review from February 1,1927 , to December 31, 1947. An explanation is given of the meaning of the various symbols used in the seven columns, and at the end of each month the mean daily area and the mean relative sunspot number are given.

\section{Colonial Service: Recent Appointments}

THE following appointments in the Colonial Service have recently been announced: W. E. M. Logan (assistant conservator of forests, Kenya), regional assistant conservator of forests, Tanganyika; P. S. Hammond (agricultural officer, Gold Coast), assistant director of agriculture (cocoa industry), Gold Coast ; J. B. D. Robinson (chemist, Department of Science and Agriculture, Barbados), scientific officer, agricultural chemist, Kenya; J. M. Waterston (senior botanist, Nigeria), principal research officer, Agriculture Department, Nigeria ; G. C. Witt (soil survey officer, Trinidad), soil chemist, Trinidad; Dr. S. E. Piercy (senior veterinary research officer, Kenya), chief veterinary research officer, Kenya; J. F. C. Swan (senior veterinary officer, Northern Rhodesia), chief animal husbandry officer, Northern Rhodesia; S. B. Chambers (statistician, Nigeria), government statistician, Nigeria; H. A. Darby, R. E. Osborne and I. H. Tomlinson (agricultural officers, Jamaica), senior agricultural officers, Jamaica; H. C. Peisley (assistant government pharmacist, Fiji), government pharmacist and medical storekeeper, Fiji; G. E. Redshaw (agricultural assistant, Jamaica), agricultural officer, Jamaica; R. O. Williams (agricultural officer, Kenya), chief research officer, Agricultural Department, British Guiana; W. H. Andrews and D. A. L. Brown, agricultural officers, Tanganyika; R. E. H. Atkinson, agricultural officer, Uganda; A. M. Cockburn, agricultural officer, Nigeria; J. R. Dunsmore and M. J. Smith, agricultural officers, Federation of Malaya; J. R. Peberdy, agricultural officer, Kenya; J. W. Reed, agricultural officer, Nyasaland ; E. A. Riley, plant pathologist, Northern Rhodesia; G. Fry and J. S. Spears, assistant conservators of forests, Kenya; E. Williams, geologist, Uganda; Miss H. G. T. Maycock, pathologist,
Federation of Malaya; J. Riley, scientific officer (entomologist, W.A.P.I.R.U.), Nigeria; J. Smartt, plant breeder/scientific officer, Northern Rhodesia; M. C. Butler, veterinary officer, Kenya; R. H. Johnson, veterinary education officer, Nigeria; A. Beaton, assistant conservator of forests, Uganda; M. J. Berry, assistant conservator of forests, Federation of Malaya; B. M. Brown, meteorologist, West African Meteorological Service, Nigeria; J. A. Channon, meteorologist, East Africa High Commission; P. B. Cornwall, entomologist, West African Cocoa Research Institute, Gold Coast ; H. F. Lamprey, biologist, Game Department, Tanganyika; W. McC. Lyall, field geologist, Kenya; P. F. Neal, field officer, Geological Survey Department, Uganda ; C. J. Swanson, meteorologist, East Africa Meteorological Department, East Africa High Commission ; D. C. Upton, statistician, East Africa High Commission ; J. A. Willby, livestock officer, Tanganyika ; A. C. Williamson, assistant conservator of forests, British Honduras.

\section{Announcements}

Prof. P. M. S. Blacketr, Jangworthy professor of physics in the University of Manchester, has been appointed to the University chair of physics tenable at the Imperial College of Science and Technology, London. The title of reader in organic chemistry in the University has been conferred on Dr. L. N. Owen in respect of the post held by him in the Imperial College.

Prof. James Chester Bradley, professor emeritus of entomology, Cornell University, one of the United States representatives on the International Commission on Zoological Nomenclature since 1944, has been elected president of the Commission, in succession to the late Dr. James Lee Peters, Museum of Comparative Zoology at Harvard College, Cambridge, Mass.

Sir Charles Darwin has been appointed chairman of the Radioactive Substances Advisory Committee in succession to Sir Henry Dale, who has resigned. Prof. G. R. Cameron (University College Hospital Medical School) and Prof. K. G. Emeléus (Queen's University, Belfast) have been appointed to the Committee.

The fourth annual conference of the Society for the Study of Fertility will be held in the University of Liverpool during July 7-8, 1953. Further particulars can be obtained from the honorary secretary, Dr. G. I. M. Swyer, at University College Obstetric Hospital, Huntley Street, London, W.C.1.

Aт a meeting of former members of the late Scottish Seaweed Research Association, those present determined to form a Society to be known as the Seaweed Utilization Society, to serve as a two-way channel of information and opinion with the Institute of Seaweed Research. The secretary of the Society is Miss M. D. Walker, 49 Rodney Street, Liverpool 1.

THE Oil and Colour Chemists' Association will hold its 1953 conference at Eastbourne during June 2-6. The general theme will be "The Optical Properties of Films of Surface Coating Materials", and there will be three technical sessions, each of three papers, on the mornings of June 3-5. Hotel reservations must be completed before January 1 on the appropriate form, obtainable from the general secretary of the Association at Memorial Hall, Farringdon Street, London, E.C.4. 